\title{
Sistem Pendukung Keputusan Pemilihan Laptop Menggunakan Metode Topsis
}

\author{
Fei Lie ${ }^{1}$, T.Tingastuti ${ }^{2}$ \\ ${ }^{1}$ Teknik Informatika, Sekolah Tinggi Teknologi Cahaya Surya Kediri \\ ${ }^{2}$ Sekolah Tinggi Teknologi Cahaya Surya Kediri \\ E-mail: ${ }^{1}$ feilie214@gmail.com, ${ }^{2}$ mariasurjosuseno@gmail.com
}

\begin{abstract}
ABSTRAK
Laptop merupakan Perangkat Komputer yang memiliki fungsi sama persis dengan Komputer Desktop/ PC Desktop. Semakin majunya teknologi, laptop dikembangkan oleh masing-masing pemegang merk/brand dengan berbagai macam feature. Perubahan desain mengalami perkembangan yang sangat pesat, baik dari segi desain, kecepatan laptop, serta penambahan fitur-fitur yang lengkap. Pada saat ini, laptop juga dijual dengan harga relatif murah dan bisa menyesuaikan budget pengguna. Hal ini bisa dijadikan alternatif pengguna untuk memiliki perangkat elektronik laptop dengan harga yang relatif terjangkau. Sistem pendukung keputusan pemilihan laptop menggunakan metode TOPSIS ini dipilih karena mampu memilih alternatif terbaik dari sejumlah alternatif. Dalam hal ini alternatif yang dimaksud adalah laptop terbaik berdasarkan kriteria-kriteria yang ditentukan dengan langkah-langkah metode TOPSIS yang sederhana, mudah dipahami, efektif dan efisien. Proses implementasi metode TOPSIS ini dapat menghasilkan urutan alternatif dari nilai yang terbesar ke nilai yang terkecil, sehingga diharapkan laptop yang direkomendasikan benar - benar sesuai dengan keinginan, kebutuhan, dan kemampuan pengguna.
\end{abstract}

Kata Kunci-Topsis, Sistem Pendukung Keputusan, Pemilihan Laptop. 


\begin{abstract}
Laptop is a Computer Device that has the same function as Desktop Computers / Desktop PCs. The more advanced technology, laptops are developed by each brand / brand holder with various features. The design changes are very fast, both in terms of design, laptop speed, and complete features. At this time, laptops are also sold at relatively cheap prices and can adjust the user's budget. This can be used as an alternative user to have a laptop electronic device at a relatively affordable price. The laptop decision support system using the TOPSIS method was chosen because it offers the best choice of alternative recommendations. In this case the approved alternative is the best laptop based on the criteria determined by the TOPSIS method steps that are simple, easy to understand, effective and efficient. The process of implementing the TOPSIS method can produce an alternative sequence of values calculated into the highest value, so it is expected that the recommended laptop is truly in accordance with the wishes, needs, and capabilities of the user.
\end{abstract}

Keywords - Topsis, Decision Support System, Laptop Selection. 


\section{PENDAHULUAN}

Laptop merupakan Perangkat Komputer yang memiliki fungsi sama persis dengan Komputer Desktop/ PC Desktop. Laptop atau Notebook memiliki design yang khusus dimana bisa dibawa kemana saja atau bersifat portable. Kekhususan pada laptop yaitu memiliki design yang relatif kecil dan ringan bila dibandingkan dengan Desktop Komputer.

Semakin majunya teknologi, laptop dikembangkan oleh masing-masing pemegang merk/brand dengan berbagai macam feature. Perubahan desain mengalami perkembangan yang sangat pesat, baik dari segi desain, kecepatan laptop, serta penambahan fitur-fitur yang lengkap. Pada saat ini, laptop juga dijual dengan harga relatif murah dan bisa menyesuaikan budget pengguna. Hal ini bisa dijadikan alternatif pengguna untuk memiliki perangkat elektronik laptop dengan harga yang relatif terjangkau.

Sistem pendukung keputusan pemilihan laptop menggunakan metode TOPSIS ini dipilih karena mampu memilih alternatif terbaik dari sejumlah alternatif. Alternatif yang dimaksud adalah laptop terbaik berdasarkan kriteria - kriteria yang ditentukan dengan langkah - langkah metode TOPSIS yang sederhana, mudah dipahami, efektif dan efisien. Proses implementasi metode TOPSIS ini dapat menghasilkan urutan alternatif dari nilai yang terbesar ke nilai yang terkecil, sehingga diharapkan laptop yang direkomendasikan benar - benar sesuai dengan keinginan, kebutuhan, dan kemampuan pengguna.

Penelitian sejenis yang berhubungan dengan penelitian ini dilakukan oleh Murnawan, Akhmad Fadjar Siddiq (2012). Ruang lingkup permasalahan hanya mencakup penilaian yang digunakan untuk mendukung pengambilan keputusan pemilihan telepon seluler menggunakan metode Technique for Order Preference by Similarity to Ideal Solution (TOPSIS), dan rating kecocokan setiap alternatif pada setiap kriteria dan tingkat kepentingan pada setiap kriteria dalam mendukung keputusan ditentukan melalui nilai angka (numeric). Tujuan dari penelitian ini yaitu diharapkan penerapan metode TOPSIS pada sistem pendukung keputusan pemilihan telepon seluler menjadi salah satu sistem pendukung keputusan yang dapat diandalkan untuk memudahkan proses pengambilan keputusan pemilihan telepon seluler berdasarkan kualitasnya [1]. Penelitian lain dilakukan oleh Pendik Pratama (2016). Penelitian ini menghasilkan sebuah aplikasi web yang memberikan informasi rekomendasi kepada 
user atau pengguna dalam hal ini merupakan calon wisatawan. Rekomendasi yang diberikan sistem didasarkan pada kriteria penilaian dan bobot kriteria setiap objek wisata kemudian diproses menggunakan metode Topsis sehingga menghasilkan rekomendasi daftar tempat wisata [2].

\section{DASAR TEORI}

\subsection{Sistem Pendukung Keputusan}

Decision Support System didefinisikan sebagai sistem computer yang mampu memberikan kemampuan baik kemampuan pemecahan masalah maupun kemampuan pengkomunikasian untuk masalah semi terstruktur. Secara khusus, DSS didefinisikan sebagai sebuah sistem yang mendukung kerja seorang manager maupun sekelompok manager dalam memecahkan masalah semi terstruktur dengan cara memberikan informasi ataupun usulan menuju pada keputusan tertentu. DSS ini bisa berbentuk sistem manual maupun sistem terkomputerisasi

\subsection{Metode AHP}

Analytical Hierarchical Process (AHP) merupakan hierarki dengan input atau masukan utama berupa pandangan manusia. Dikembangkan oleh Prof. Thomas Lorie Saaty dari Wharton Business School awal tahun 1970. Metode ini gunakan untuk mencari urutan atau ranking prioritas dari berbagai alternatif dalam pemecahan masalah. AHP banyak digunakan untuk mengekspresikanpengambilan suatu keputusan yang sangat efektif dari suatu permasalahan yang komplek. Penentuan prioritas dengan metode AHP dilakukan melalui beberapa tahapan yaitu:

a. Menyusun hierarki.

b. Menilai kriteria dan alternatif.

c. Memilih prioritas.

d. Menentukan nilai konsistensi logis.

Di dalam mengambil keputusan, penting untuk diketahui baik tidaknya nilai konsistensi yang digunakan. Adapun langkah-langkah yang harus dilakukan adalah:

1. Menghitung nilai perbandingan yang sudah ditetapkan dengan membagi nilai skala yang ada di setiap sel dibagi dengan nilai sel prioritas.

2. Hasil pehitungan dari langkal no. 1 di masingmasing sel dibagi dengan jumlah total di masingmasing kolom.

3. Mencari Eigen dengan cara menghitung ratarata per baris. 
4. Mencari Lamda $(\lambda)$ dengan cara mengalikan masing-masing nilai eigen per baris dengan jumlah total per kolom.

5. Mencari lamda ( $\lambda$ maks) dengan cara menjumlahkan hasil lamda

\section{METODE PENELITIAN}

Metodologi penelitian Sistem Pendukung Keputusan Pemilihan Laptop Menggunakan Metode Topsis.

\subsection{Pengumpulan Data}

Sebelum membuat aplikasi yang diperlukan, dilakukan pengumpulan data terlebih dahulu. Pengumpulan data dapat dilakukan dengan beberapa cara, yaitu :

\section{a. Data Internal}

- Interview yaitu dengan cara pengumpulan data dilakukan dengan cara tanya jawab secara langsung dengan pemilik Toko Raja Computer

- Pengamatan langsung ke tempat penelitian dan tanya jawab dengan pengunjung mengenai pemilihan laptop yang saya teliti.

- Studi Dokumen yaitu jenis pengumpulan data yang meneliti atau menganalisis data laptop.

\section{b. Data Eksternal}

Studi Literatur yaitu studi keputusan bertujuan untuk mendapatkan pengertian secara teori melalui sumber dari buku-buku.

\subsection{Analisis Data}

Proses analisis data menggunakan Metode TOPSIS. Metode TOPSIS didasarkan pada konsep dimana alternatif terpilih yang terbaik tidak hanya memiliki jarak terpendek dari solusi ideal positif, namun juga memiliki jarak terpanjang dari solusi ideal negatif (Hwang, 1981) (Zeleny, 1982). Konsep ini banyak digunakan pada beberapa model MADM untuk menyelesaikan masalah keputusan secara praktis (Hwang, 1993), (Liang, 1999), (Yeh, 2000). Hal ini disebabkan : konsepnya yang sederhana dan mudah dipahami; komputasinya efisien; dan memiliki kemampuan untuk mengukur kinerja relatif dari alternatif-alternatif keputusan dalam bentuk matematis yang sederhana. Secara umum, prosedur TOPSIS mengikuti langkah-langkah sebagai berikut :

- Membuat matriks keputusan yang ternormalisasi.

- Membuat matriks keputusan yang ternormalisasi terbobot. 
- Menentukan matriks solusi ideal positif \& matriks solusi ideal negatif.

- Menentukan jarak antara nilai setiap alternatif dengan matriks solusi ideal positif \& matriks solusi ideal negatif.

- Menentukan nilai preferensi untuk setiap alternatif.

TOPSIS membutuhkan rating kinerja setiap alternatif $A_{i}$ pada setiap kriteria $C_{j}$ yang ternormalisasi, yaitu

$$
r_{i j}=\frac{x_{i}}{\sqrt{\sum_{i=1}^{m l} x_{i}^{2}}}(1) .
$$

Dengan $\mathrm{i}=1,2, \ldots, \mathrm{m} ;$ dan $\mathrm{j}=1,2, \ldots, \mathrm{n}$;

Solusi ideal positif $\mathrm{A}^{+}$dan solusi ideal negatif $\mathrm{A}^{-}$dapat ditentukan berdasarkan rating bobot ternormalisasi $\left(\mathrm{y}_{\mathrm{ij}}\right)$ sebagai :

$$
y_{i j}=w_{i} r_{i j}
$$

dengan $i=1,2 \ldots, m$ dan $j=1,2, \ldots, n$.

$$
\begin{aligned}
& A^{+}=\left(y_{1}^{+}, y_{2}{ }^{+}, \ldots, y_{n}^{+}\right) \\
& A^{-}=\left(y_{1}^{-}, y_{2}^{-}, \ldots, y_{n}^{-}\right)
\end{aligned}
$$

Dengan

$$
\begin{aligned}
& y_{j}^{+}=\left\{\begin{array}{ccccccc}
m & i & y_{i} & j i & j a & h a & k \\
& m & & & & & \\
& y_{i} & j i & j a & h a & & b
\end{array}\right.
\end{aligned}
$$

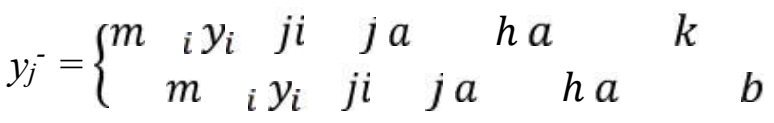

$\mathrm{j}=1,2, \ldots, \mathrm{n}$.

Jarak antara alternatif $A_{i}$ dengan solusi ideal positif dirumuskan sebagai :

$$
D_{i}^{+}=\sqrt{\sum_{j=1}^{n}\left(y_{i}^{+}-y_{i}\right)^{2}}
$$

$\mathrm{i}=1,2, \ldots, \mathrm{m}$.

Jarak antara alternatif $A_{i}$ dengan solusi ideal negatif dirumuskan sebagai :

$$
D_{i}^{-}=\sqrt{\sum_{j=1}^{n}\left(y_{i}-y_{i}^{-}\right)^{2}}
$$

$\mathrm{i}=1,2, \ldots, \mathrm{m}$.

Nilai preferensi untuk setiap alternatif $\left(\mathrm{V}_{\mathrm{i}}\right)$ diberikan sebagai : 


$$
V_{i}=\frac{D_{i}^{-}}{D_{i}^{-}+D_{i}^{+}}
$$

Nilai $V_{i}$ yang lebih besar mengindikasikan bahwa alternatif $A_{i}$ lebih dipilih. [3]

\subsection{Perancangan Sistem}

Setelah menganalisis dan mengetahui kebutuhan yang diperlukan, harus melewati tahap perancangan sistem terlebih dahulu, agar mempermudah proses pembuatan sistem ini, dan agar langkah - langkah sistem lebih terstruktur

\section{A. Context Diagram}

Context Diagram merupakan tingkatan tertinggi dalam diagram aliran data dan hanya memuat satu proses, menunjukkan sistem secara keseluruhan. Proses tersebut diberi nomor nol. Semua entitas eksternal yang ditunjukkan pada diagram konteks berikut aliran data-aliran data utama menuju dan dari sistem. Diagram tersebut tidak memuat penyimpanan data dan tampak sederhana untuk diciptakan, begitu entitasentitas eksternal serta aliran data-aliran data menuju dan dari sistem diketahui menganalisis dari wawancara dengan user dan sebagai hasil analisis dokumen. [4]

Tabel 1. Simbol Context Diagram

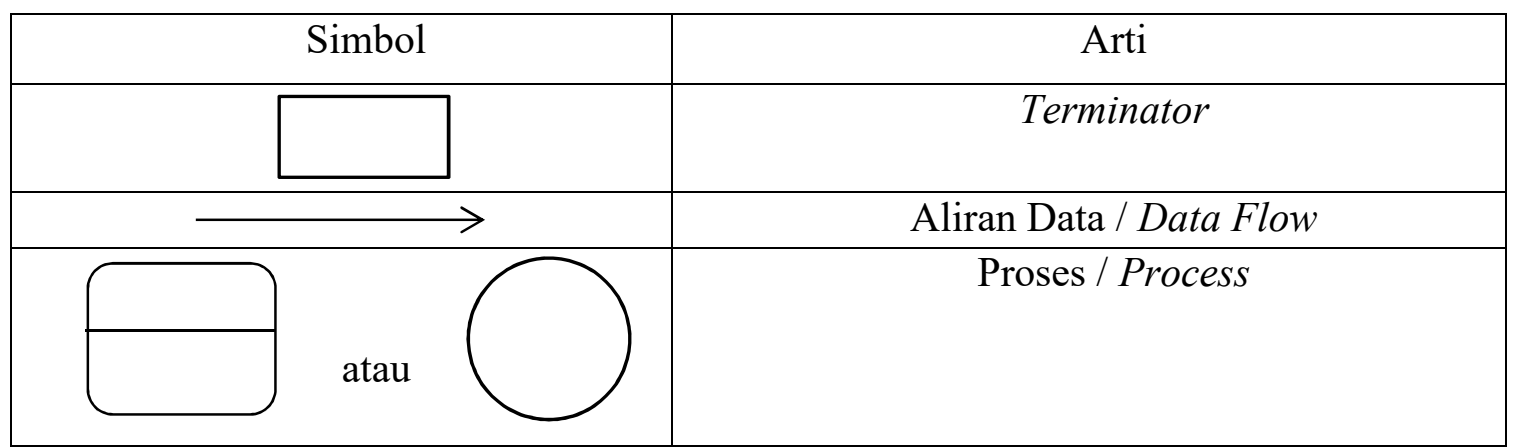

\section{Data Flow Diagram}

Diagram Alir Data (DAD) atau Data Flow Diagram (DFD) adalah suatu diagram yang menggunakan notasi-notasi untuk menggambarkan arus dari data sistem, yang penggunaannya sangat membantu untuk memahami sistem secara logika, tersruktur dan jelas. DFD merupakan alat bantu dalam menggambarkan atau menjelaskan DFD ini sering disebut juga dengan nama Bubble chart, Bubble diagram, model proses, diagram alur kerja, atau model fungsi. [4] 
Tabel 2 Simbol DFD

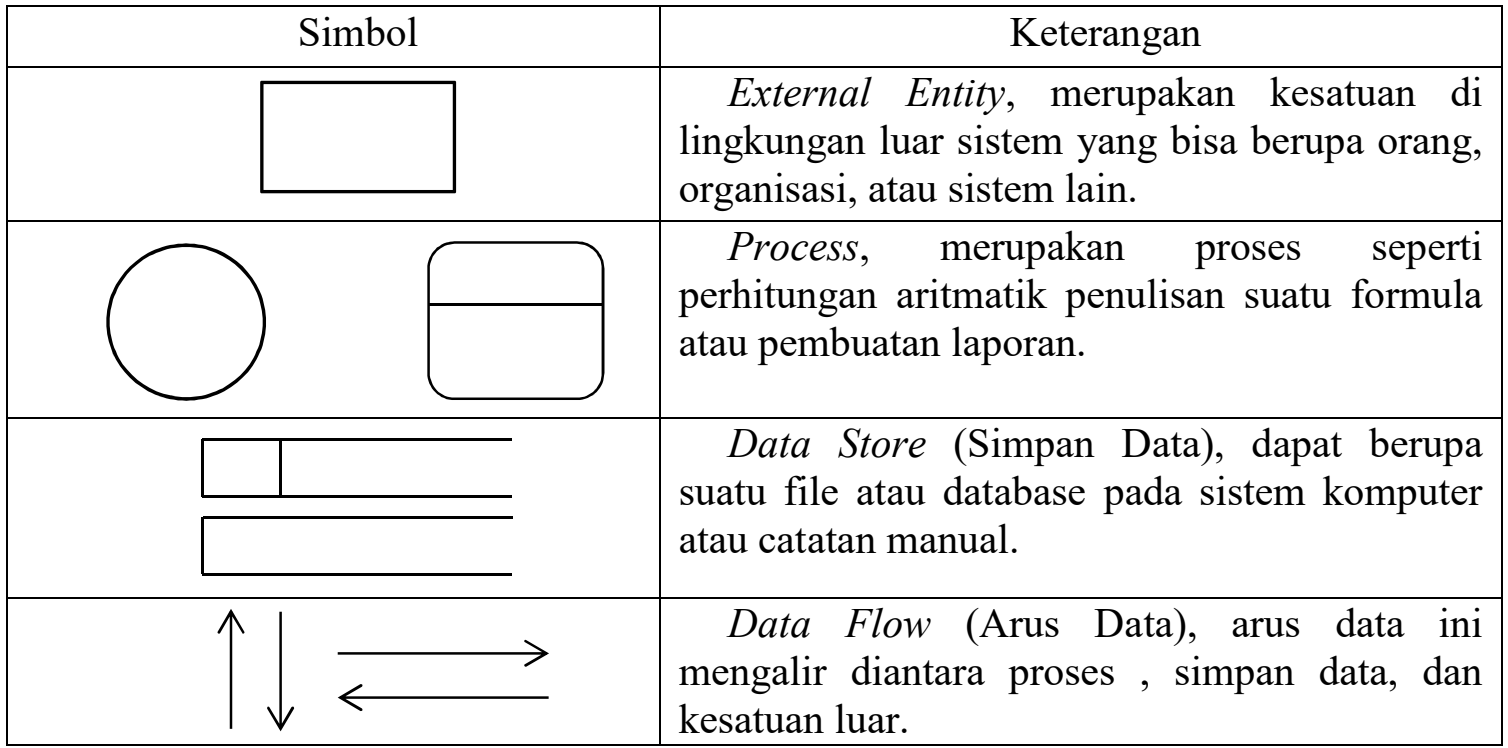

\subsection{Implementasi}

Implementasi database, yaitu membuat database pada MySQL sesuai dengan rancangan database yang telah dibuat, serta implementasi antar muka pengguna, tampilan juga disesuaikan seperti rancangan yang dibuat. Setelah merancang tampilan, kemudian melakukan koding pada aplikasi. Kemudian dikoneksikan diantara database dengan tampilan antar muka pengguna

\section{HASIL DAN PEMBAHASAN}

\subsection{Rancangan Sistem}

Konteks Diagram untuk Sistem Pendukung Keputusan Pemilihan Laptop Menggunakan Metode Topsis dapat dilihat pada Gambar 1

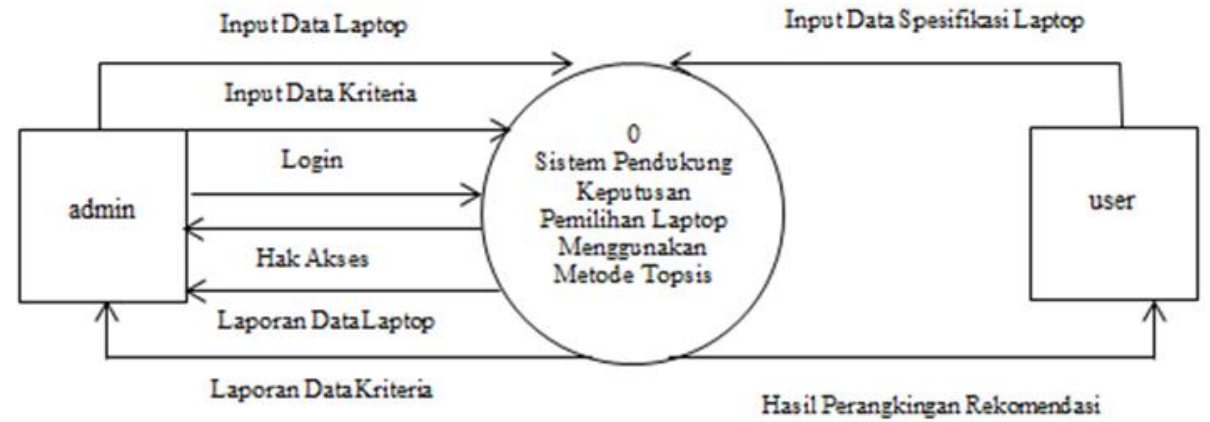

Gambar 1.Context Diagram

Pada conteks diagram diatas, pertama admin login ke sistem. Setelah login, admin memiliki hak akses dan dapat menginputkan data laptop, dan data kriteria ke sistem. 
Setelah itu, sistem memberikan laporan data laptop dan data kriteria ke admin. User menginputkan data spesifikasi laptop, setelah itu sistem memberikan hasil perangkingan rekomendasi pemilihan laptop menggunakan metode Topsis.

DFD Level 0 untuk Sistem Pendukung Keputusan Pemilihan Laptop Menggunakan Metode Topsis dapat dilihat pada Gambar 2.

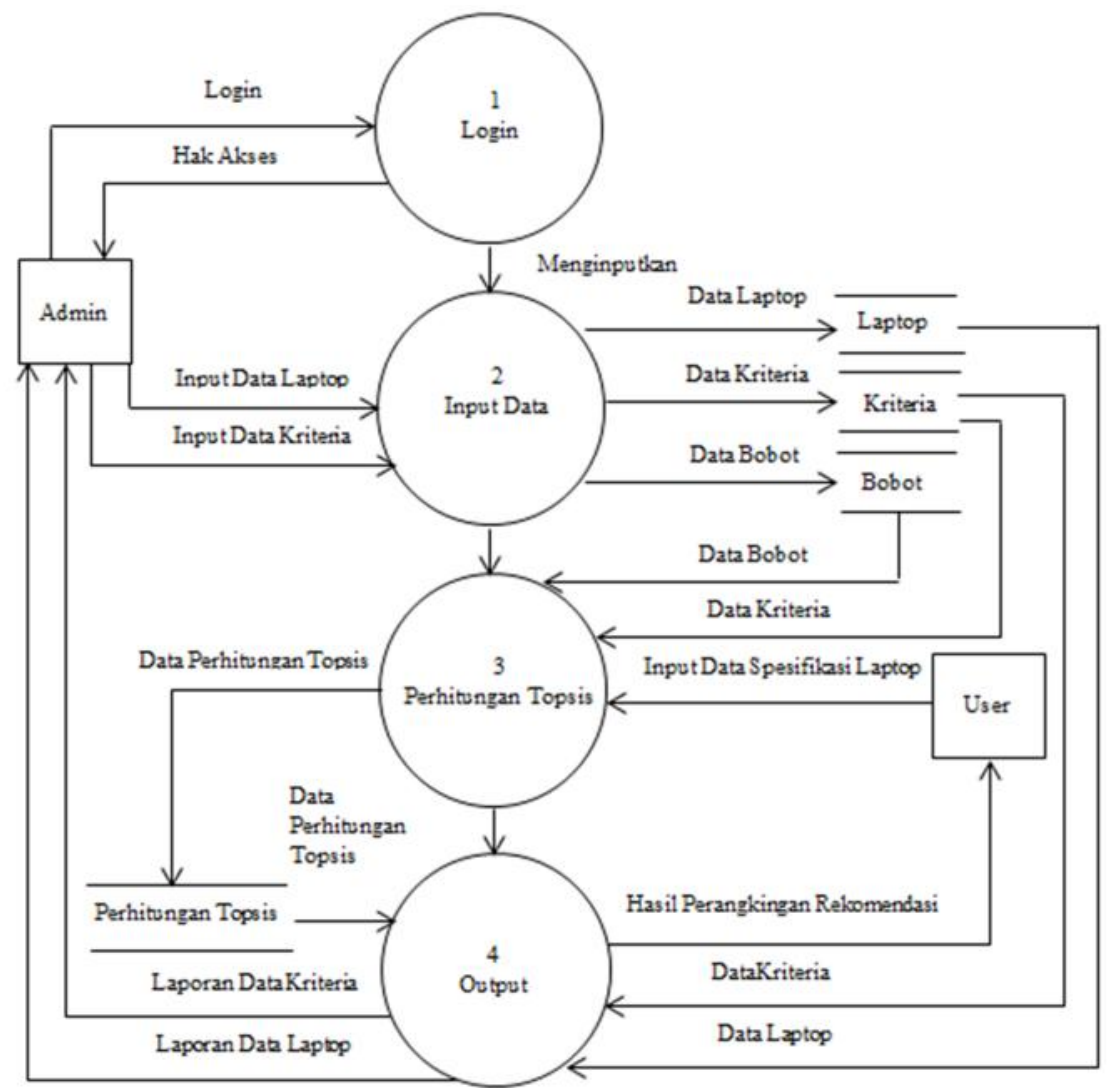

Gambar 2. DFD Level 0

Proses pertama adalah proses login. Admin login dan mendapatkan hak akses. Proses kedua adalah proses input data. Setelah mendapatkan hak akses admin menginputkan data laptop, kriteria, dan bobot. Proses ketiga adalah proses perhitungan topsis. Data kriteria dan bobot masuk ke proses perhitungan topsis dan user menginputkan data spesifikasi laptop yang diinginkan. Proses keempat adalah output. Setelah perhitungan topsis selesai user mendapatkan hasil perangkingan rekomendasi pemilihan laptop dan admin mendapat laporan data kriteria dan laptop.

DFD Level 1 Proses Perhitungan Topsis untuk Sistem Pendukung Keputusan Pemilihan Laptop Menggunakan Metode Topsis dapat dilihat pada Gambar 3 


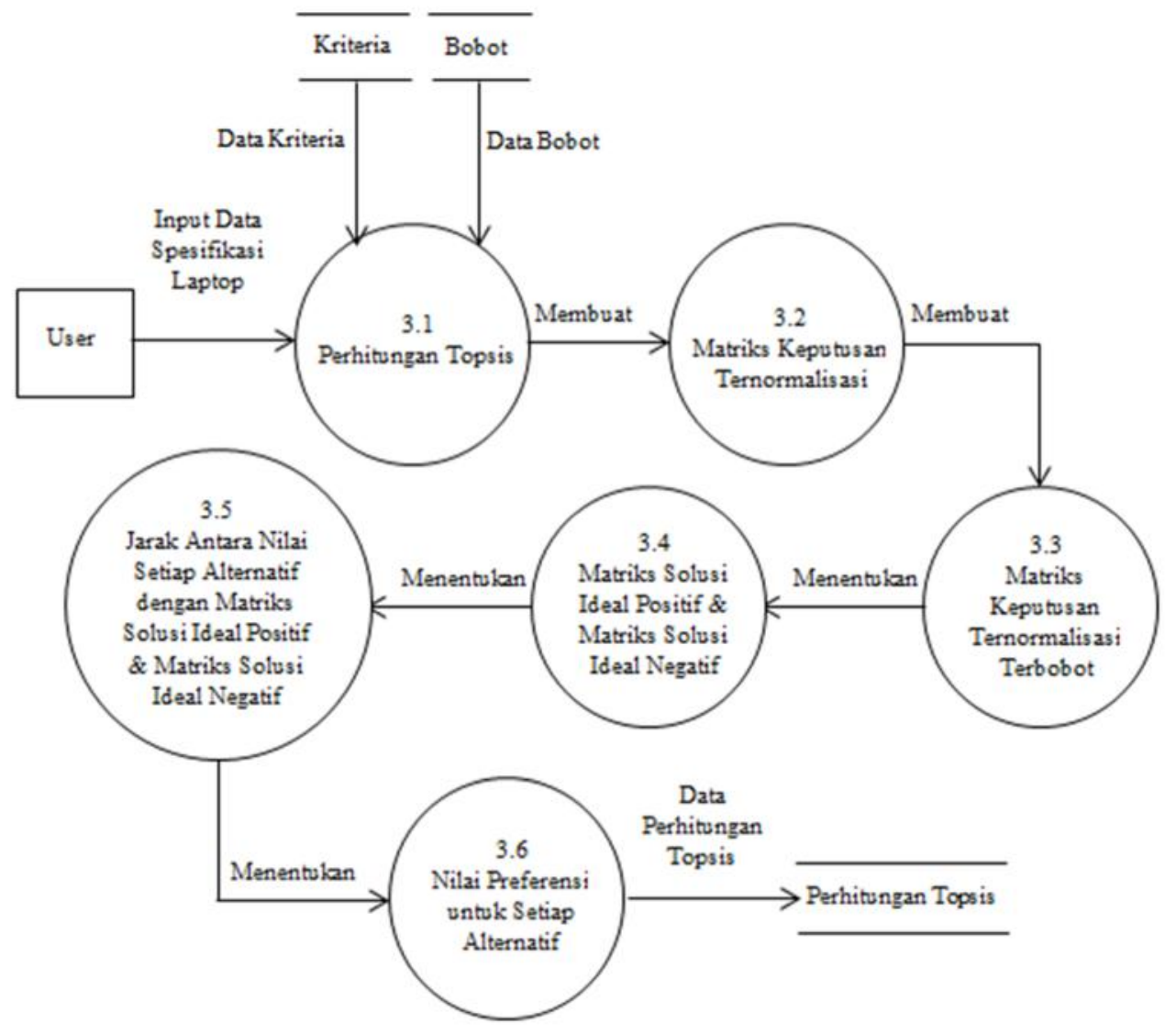

\section{Gambar 3. DFD Level 1 Proses Perhitungan Topsis}

Pada proses perhitungan topsis, user menginputkan data spesifikasi laptop yang diinginkan. Data kriteria dan bobot masuk ke proses Perhitungan Topsis. Setelah itu, membuat Matriks Keputusan Ternormalisasi, membuat Matriks Keputusan Ternormalisasi Terbobot, menentukan Matriks Solusi Ideal Positif \& Matriks Solusi Ideal Negatif, menentukan Jarak Antara Nilai Setiap Alternatif dengan Matriks Solusi Ideal Positif \& Matriks Solusi Ideal Negatif, dan proses terakhir yaitu menentukan Nilai Preferensi untuk Setiap Alternatif

\subsection{Interface}

\subsubsection{Interface Input Data Laptop}

Admin menginputkan data laptop yang terdiri dari Tipe Laptop, VGA, Processor, RAM, dan HDD. 


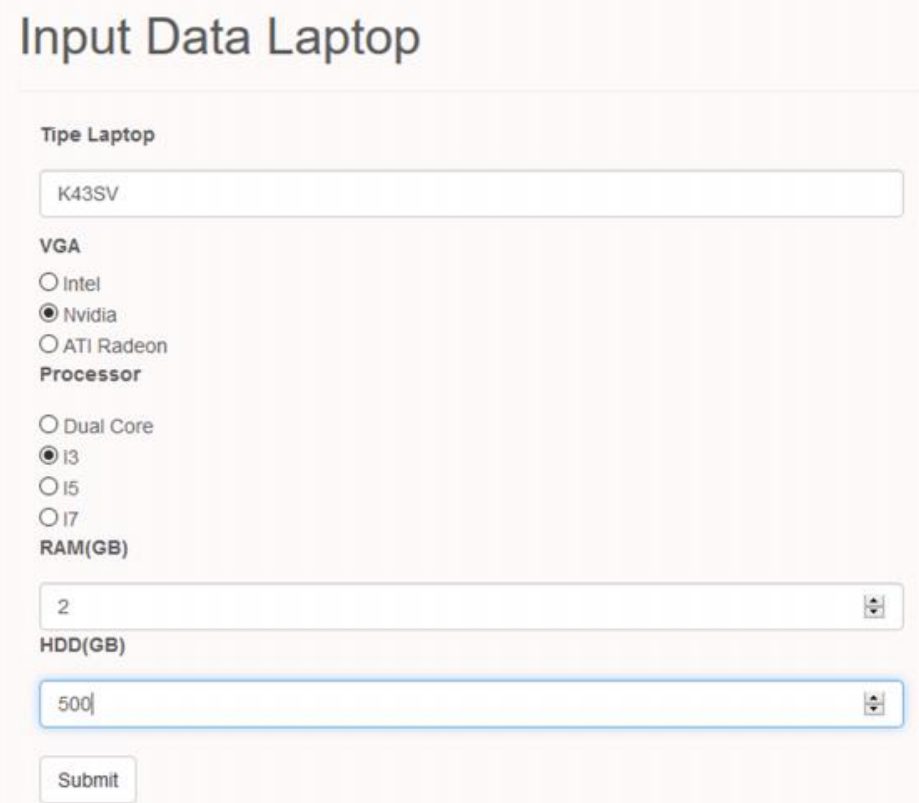

Gambar 4. Input Data Laptop

\subsubsection{Interface Input Data Kriteria}

Admin menginputkan ID Laptop, Merk Laptop, Ukuran Layar, VGA, Harga, dan Processor.

\section{Input Data Kriteria}

\begin{tabular}{|c|c|}
\hline 1 & \\
\hline \multicolumn{2}{|c|}{ Merk Laptop } \\
\hline \multicolumn{2}{|c|}{ OAsus OAcer Olenovo } \\
\hline \multicolumn{2}{|c|}{ Ukuran Layar(Inch) } \\
\hline 14 & $\div$ \\
\hline \multicolumn{2}{|l|}{ VGA(GB) } \\
\hline 1 & $\div$ \\
\hline \multicolumn{2}{|l|}{ Harga(Rp) } \\
\hline 5300000 & $\div$ \\
\hline \multicolumn{2}{|c|}{ Processor(Ghz) } \\
\hline 1.8 & $\div$ \\
\hline Submit & \\
\hline
\end{tabular}

Gambar 5. Input Data Kriteria 


\section{Interface Rekomendasi}

User dapat memilih laptop yang akan dibandingkan untuk keperluan Gamming, Kantor, atau Pendidikan. Setelah itu, user mencentang kotak disebelah kiri data laptop yang akan dibandingkan dan tekan tombol Bandingkan.

\section{Pilih Beberapa Jenis Laptop yang ingin dibandingkan(Pendidikan)}

\begin{tabular}{|c|c|c|c|}
\hline \multicolumn{4}{|c|}{$\begin{array}{l}\text { - Gamming } \\
\text { - Kantor } \\
\text { - Pendidikan }\end{array}$} \\
\hline & ID PC & Merk & Tipe \\
\hline$\square$ & 1 & Asus & K43SV \\
\hline$\square$ & 3 & Lenovo & Edge E440 \\
\hline$\square$ & 4 & Acer & AspireOne \\
\hline$\square$ & 5 & Asus & A67T \\
\hline$\square$ & 6 & Acer & Aspire X \\
\hline घ & 7 & Acer & E5 - 473 \\
\hline$\square$ & 8 & Asus & A455LF \\
\hline 口 & 9 & Lenovo & IP 110 \\
\hline$\square$ & 10 & Acer & E5 - 473 \\
\hline$\square$ & 11 & Asus & X302UV \\
\hline$\square$ & 12 & Asus & A456U \\
\hline$\square$ & 13 & Asus & A555L \\
\hline$\square$ & 14 & Asus & P2420L \\
\hline$\square$ & 15 & Asus & A456UQ \\
\hline$\square$ & 16 & Asus & A455LD \\
\hline$\square$ & 17 & Asus & A455LB \\
\hline$\square$ & 18 & Asus & X450JB \\
\hline$\square$ & 19 & Lenovo & $G 40-80$ \\
\hline$\square$ & 20 & Lenovo & $G 40-80$ \\
\hline
\end{tabular}

\begin{tabular}{llllll} 
Layar(Inch) & Processor Harga & VGA & RAM(GB) & HDD(GB) \\
\hline 14 & $13-1.8 \mathrm{Ghz}$ & 5300000 & nvidia-1GB & 2 & 500 \\
\hline 14 & $17-2.8 \mathrm{Ghz}$ & 7000000 & ati radeon-2GB & 4 & 2000 \\
\hline 14 & $17-3.8 \mathrm{Ghz}$ & 7500000 & ati radeon-2GB & 4 & 2000 \\
\hline 14 & $17-3.6 \mathrm{Ghz}$ & 7700000 & nvidia-2GB & 8 & 4000 \\
\hline 14 & $13-1.6 \mathrm{Ghz}$ & 5500000 & intel-1GB & 2 & 1000 \\
\hline 14 & $13-2 \mathrm{Ghz}$ & 5600000 & nvidia-2GB & 4 & 500 \\
\hline 14 & $13-2 \mathrm{Ghz}$ & 5700000 & nvidia-2GB & 4 & 500 \\
\hline 14 & $17-2.5 \mathrm{Ghz}$ & 7700000 & ati radeon-2GB & 4 & 1000 \\
\hline 14 & $15-2.3 \mathrm{Ghz}$ & 7300000 & nvidia-2GB & 4 & 1000 \\
\hline 13 & $15-2.3 \mathrm{Ghz}$ & 7550000 & nvidia-2GB & 4 & 1000 \\
\hline 14 & $15-2.3 \mathrm{Ghz}$ & 8700000 & nvidia-2GB & 4 & 1000 \\
\hline 15.5 & $13-1.7 \mathrm{Ghz}$ & 5350000 & nvidia-2GB & 2 & 500 \\
\hline 14 & $15-2.2 \mathrm{Ghz}$ & 8950000 & nvidia-2GB & 4 & 1000 \\
\hline 14 & $17-2.7 \mathrm{Ghz}$ & 9000000 & nvidia-2GB & 4 & 1000 \\
\hline 14 & $17-3.1 \mathrm{Ghz}$ & 9450000 & nvidia-2GB & 4 & 1000 \\
\hline 14 & $15-2.2 \mathrm{Ghz}$ & 7825000 & nvidia-2GB & 4 & 1000 \\
\hline 14 & $17-2.6 \mathrm{Ghz}$ & 8700000 & nvidia-2GB & 4 & 1000 \\
\hline 14 & $13-1.9 \mathrm{Ghz}$ & 5300000 & ati radeon-2GB & 4 & 500 \\
\hline 14 & $15-2.7 \mathrm{Ghz}$ & 6800000 & ati radeon-2GB & 2 & 500 \\
\hline & & & & &
\end{tabular}

\section{Gambar 6. Rekomendasi - 1}

\begin{tabular}{|c|c|c|c|c|c|c|c|c|c|}
\hline 口 & 33 & Asus & $x .4415$ & 14 & $\begin{array}{l}\text { Dual Core - } \\
16 \mathrm{Gnz}\end{array}$ & 3500000 & Intel - 1GB & 2 & 500 \\
\hline$\square$ & 34 & Asus & TP201SA & 11.6 & $\begin{array}{l}\text { Dual Core - } \\
2.56 \mathrm{Gnz}\end{array}$ & 5000000 & Intel - 1GB & 4 & 500 \\
\hline$\square$ & 35 & Lenovo & 310 S-11AAP & 11.6 & $\begin{array}{l}\text { Dual Core- } \\
24 \mathrm{G} / \mathrm{z}\end{array}$ & 2950000 & intel - 1GB & 2 & 500 \\
\hline 口 & 36 & Lenovo & IP 110 & 14 & $\begin{array}{l}\text { Dual Core - } \\
1.6 \mathrm{Gnz}\end{array}$ & 3500000 & intel - 2GB & 4 & 500 \\
\hline$\square$ & 37 & Lenovo & IP 110 & 14 & $\begin{array}{l}\text { Dual Core - } \\
1.6 \mathrm{Gm}\end{array}$ & 3550000 & intel - 1GB & 2 & 500 \\
\hline 口 & 38 & Acer & $23-451$ & 14 & $\begin{array}{l}\text { Dual Core - } \\
\text { 3.5Gnz }\end{array}$ & 6700000 & att radeon-2GB & 4 & 500 \\
\hline$\square$ & 39 & Asus & X540YA & 15.6 & $\begin{array}{l}\text { Dual Core - } \\
1.5 \mathrm{Gnz}\end{array}$ & 3500000 & at radeon $-2 \mathrm{~GB}$ & 2 & 500 \\
\hline 口 & 40 & Asus & X454Y & 14 & $\begin{array}{l}\text { Dual Core - } \\
22 \mathrm{Gmz}\end{array}$ & 4900000 & at radeon $-2 G B$ & 4 & 500 \\
\hline$\square$ & 41 & Asus & X555DG & 15.6 & $\begin{array}{l}\text { Dual Core - } \\
3.2 \mathrm{Gnz}\end{array}$ & 6850000 & at radeon $-2 \mathrm{~GB}$ & 4 & 1000 \\
\hline 口 & 42 & Asus & X550ZE & 15.6 & $\begin{array}{l}\text { Dual Core - } \\
3.6 \mathrm{Gnz}\end{array}$ & 5600000 & at radeon - $2 \mathrm{~GB}$ & 2 & 500 \\
\hline 口 & 43 & Asus & X555DQ & 15.6 & $\begin{array}{l}\text { Dual Core- } \\
\text { 3.3Gnz }\end{array}$ & 7200000 & at radeon $-2 \mathrm{~GB}$ & 4 & 1000 \\
\hline 口 & 44 & Asus & X5550G & 15.6 & $\begin{array}{l}\text { Dual Core - } \\
\text { 3.4Ghz }\end{array}$ & 7400000 & ati radeon-2GB & 8 & 1000 \\
\hline$\square$ & 45 & Lenovo & IP 110 & 14 & $\begin{array}{l}\text { Dual Core - } \\
\text { 3.5Ghz }\end{array}$ & 4300000 & at iadeon - 268 & 4 & 1000 \\
\hline$\square$ & 46 & Acer & v5 132 & 11.6 & $\begin{array}{l}\text { Dual Core - } \\
1 \text { Ghz }\end{array}$ & 3000000 & Intel - $1 G B$ & 2 & 500 \\
\hline
\end{tabular}

Gambar 7. Rekomendasi - 2 
D. Hasil Rekomendasi

Jika user telah menekan tombol Bandingkan, maka akan keluar hasil rekomendasi menggunakan metode Topsis.

\section{Tabel Nilai Preferensi (skor)}

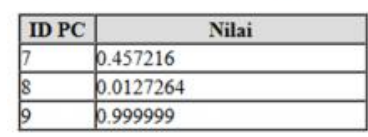

\section{Tabel Hasil Akhir}

\begin{tabular}{|l|l|l|l|l|l|l|l|l|l|}
\hline $\begin{array}{l}\text { ID } \\
\text { PC }\end{array}$ & \multicolumn{1}{|c|}{ Merk } & \multicolumn{1}{|c|}{ Tipe } & Layar(Inch) & Processor & \multicolumn{1}{|c|}{ Harga } & \multicolumn{1}{c|}{ VGA } & RAM(GB) & HDD(GB) & $\begin{array}{c}\text { Skor } \\
\text { Perbandingan }\end{array}$ \\
\hline 9 & Lenovo & IP 110 & 14 & $17-2.5 \mathrm{Ghz}$ & 7700000 & ati radeon - 2GB & 4 & 1000 & 0.999999 \\
\hline 7 & Acer & E5 - 473 & 14 & $13-2 \mathrm{Ghz}$ & 5600000 & nvidia - $2 \mathrm{~GB}$ & 4 & 500 & 0.457216 \\
\hline 8 & Asus & A $455 \mathrm{LF}$ & 14 & $13-2 \mathrm{Ghz}$ & 5700000 & nvidia - $\mathrm{GB}$ & 4 & 500 & 0.0127264 \\
\hline
\end{tabular}

\section{Gambar 8. Hasil Rekomendasi}

\section{KESIMPULAN}

\subsection{Kesimpulan}

Berdasarkan pembahasan dan evaluasi dari bab terdahulu, maka dapat ditarik kesimpulan sebagai berikut:

1. Sistem memudahkan pemilihan laptop.

2. Metode Topsis dapat diterapkan dalam Sistem Pendukung Keputusan Pemilihan

Laptop sehingga memberikan kemudahan kepada pengguna kendala hal pemilihan laptop.

\subsection{Saran}

Berikut adalah beberapa saran untuk pengembangan lebih lanjut terhadap penelitian skripsi ini:

1. Metode TOPSIS dapat digabungkan dengan metode lain, misalnya metode Analytical Hierarchy Process (AHP).

2. Sistem sebaiknya dapat menangani lebih banyak kriteria misalkan RAM, HDD, dll 


\section{DAFTAR PUSTAKA}

[1].Murnawan, Siddiq, A.F., 2012, Sistem Pendukung Keputusan Menggunakan Metode Technique for Order by Similarity to Ideal Solution (TOPSIS), Jurnal Sistem Informasi (JSI), ISSN Print : 2085-1588 ISSN Online : 2355-4614, VOL. 4 No 1, April 2012

[2]. Pendik, P., 2016, Sistem Pendukung Keputusan dalam Pemilihan Lokasi Objek Wisata Menggunakan Metode Topsis, Artikel Skripsi, Fakultas Teknik Universitas Nusantara Persatuan Guru Republik Indonesia, Kediri

[3]. Kusumadewi, S., Hartati, S., Harjoko, A., \& Wardoyo, R., 2006, Fuzzy MultiAtribute Decision Making, First Edition, Graha Ilmu, Yogyakarta

[4]. Black, R., 17 April 2017, Pengertian dan Contoh dari Context Diagram, Data Flow Diagram, dan Flow Map, www.academia.edu/6078318/Pengertian_dan_Contoh_Dari_Context_Diagram Data_Flow_Diagram_dan_Flow_Map_upload by_rahmatdi.com

[5] S. W. Mudjanarko, S. Winardi, and A. D. Limantara, "Pemanfaatan internet of things (iot) sebagai solusi manejemen transportasi kendaraan sepeda motor," Pros. Semin. Nas. Apl. Teknol. Prasarana Wil. X, no. August, 2017, doi: 10.17605/OSF.IO/6UE4B.

[6] A. D. Triono et al., "Utilization of Pedestrian Movement on the Sidewalk as a Source of Electric Power for Lighting Using Piezoelectric Censors," in 2018 3rd IEEE International Conference on Intelligent Transportation Engineering, ICITE 2018, 2018, doi: 10.1109/ICITE.2018.8492624.

[7] A. D. Limantara, L. D. Krisnawati, S. Winardi, and S. W. Mudjanarko, "Solusi Pengawasan Kebijakan Mengatasi Kemacetan Jalan dan Parkir Kota Berbasis Internet Cerdas," Semin. Nas. Teknol. dan Rekayasa Inf., no. November, pp. 1-6, 2017.

[8] A. D. Limantara, S. Winarto, and S. W. Mudjanarko, "Sistem Pakar Pemilihan Model Perbaikan Perkerasan Lentur berdasarkan Indeks Kondisi Perkerasan (Pci)," Semin. Nas. dan Teknol. Fak. Tek. Universtas Muhammadiyah Surakarta, no. November, pp. 1-2, 2017, [Online]. Available: https://jurnal.umj.ac.id/index.php/semnastek/article/view/1807.

[9] A. D. Limantara, Y. C. S. Purnomo, and S. W. Mudjanarko, "Pemodelan Sistem Pelacakan LOT Parkir Kosong Berbasis Sensor Ultrasonic Dan Internet Of Things ( IOT ) Pada Lahan Parkir Diluar Jalan," Semin. Nas. Sains dan Teknol., vol. 1, no. 2, pp. 1-10, 2017.

[10] A. D. Limantara et al., "Optimization of standard mix design of porous paving coconut fiber and shell for the parking area," in AIP Conference Proceedings, 2018, vol. 2020, doi: 10.1063/1.5062655. 
[11] A. D. Limantara, A. Widodo, S. Winarto, L. D. Krisnawati, and S. W. Mudjanarko, "Optimizing the use of natural gravel Brantas river as normal concrete mixed with quality fc $=19.3 \mathrm{Mpa}$," in IOP Conference Series: Earth and Environmental Science, 2018, vol. 140, no. 1, doi: 10.1088/17551315/140/1/012104.

[12] S. Wiwoho Mudjanarko et al., "The Concrete Quality Testing for Trapezoidal Model of the Prefabricated Foundation," Int. J. Eng. Technol., vol. 7, no. January, pp. 311-315, 2018, doi: 10.14419/ijet.v7i3.25.17588.

[13] D. A. Yulmida, S. W. Mudjanarko, M. I. Setiawan, and A. D. Limantara, "Analisis Kinerja Parkir Sepanjang Jalan Walikota Mustajab," U KaRsT, vol. Volume1, no. nomor1, pp. 39-46, 2017, doi: http://dx.doi.org/10.30737/u\%20karst.v1i1.81.

[14] A. D. Limantara, E. Gardjito, A. Ridwan, E. Sustiyatik, P. Pudijohartomo, and H. L. Sudarmanto, "The Effect of Bioconc Against Compressive Strength of Paving Concrete Combining Natural Materials," vol. 7, no. x, pp. 89-91, 2018.

[15] A. D. Limantara and S. W. Mudjanarko, "Investigasi Forensik Kerusakan Perkerasan Lentur Jalan Raya," UKaRsT, vol. 1, no. 1, pp. 85-105, 2017.

[16] E. Gardjito, A. D. Limantara, B. Subiyanto, and S. W. Mudjanarko, "Role of Project Related Parties on Quality Control (Concrete Structure) and Achievement of Project Performance," U KaRsT, vol. 2, no. 1, pp. 81-100, 2018.

[17] A. D. Limantara, E. Gardjito, B. Subiyanto, and S. W. Mudjanarko, "Modeling Decision Support to Prioritize Pavement Maintenance Activities in Indonesia," UKaRsT, vol. 2, no. 1, pp. 41-60, 2018.

[18] S. W. Mudjanarko, A. D. Limantara, B. Subiyanto, and F. Nurzandah, "Optimization of Standard Mix Design of Porous Paving Coconut Fiber for Parking Area," UKaRsT, vol. 2, no. 1, pp. 61-80, 2018.

[19] D. A. Restuti, L. Rifani, A. D. Limantara, and B. Subiyanto, "APLIKASI WEB MIX DESAIN BETON BERDASARKAN METODE DOE (SNI 03-28472002)," U KaRsT, vol. 1, no. 2, pp. 36-50, 2017.

[20] E. Gardjito, A. D. Limantara, B. Subiyanto, and S. W. Mudjanarko, "PENGENDALIAN MUTU BETON DENGAN METODE CONTROL CHART (SPC) DAN PROCESS CAPABILITY (SIX-SIGMA) PADA PEKERJAAN KONSTRUKSI," U KaRsT, vol. 1, no. 2, pp. 80-105, 2017.

[21] N. Damastuti, R. D. Nasihien, A. D. Limantara, and B. Subiyanto, "COMPUTATIONAL FLUID DYNAMICS (CFD) UNTUK SIMULASI ALIRAN FLUIDA PADA BANGUNAN MASJID UNIVERSITAS NAROTAMA," U KaRsT, vol. 1, no. 2, 2017. 
[22] A. Situmorang, A. D. Limantara, B. Subiyanto, and S. W. Mudjanarko, "PENINGKATAN DAYA DUKUNG TANAH DASAR LEMPUNG EKSPANSIF DENGAN STABILISASI KAPUR DAN GARAM," $U$ KaRsT, vol. 1, no. 2, pp. 68-79, 2017.

[23] W. ARGANATA, A. D. LIMANTARA, AND Y. CAHYO, "ANALISIS PERENCANAAN OVERLAY PADA RUAS JALAN CRAKENNGULUNGKULON NAMBAK-NGULUNGKULON DENGAN BAHAN ACL MENGGUNAKAN METODE BINA," J. MANAJ. TEKNOL. TEK. SIPIL, VOL. 2, NO. 1, PP. 121-131, 2017. 